\title{
Muslims in Norway: Value Discourses and Interreligious Dialogue
}

\author{
Oddbjørn Leirvik
}

\begin{abstract}
This article discusses value discourses among Muslims in Norway in the light of political frameworks and public debates. It particularly analyses Norwegian Muslims' relation to values associated with the welfare state and gender equality, and the role of interreligious dialogue in Norwegian society. Among the findings are, that while generational changes contribute to some young Norwegian Muslims' identification with institutionalized Norwegian values and practices related to dialogue and gender, others choose to identify with strongly conservative values, not least concerning gender; and others again, although very few, identify with Islamic political extremism.
\end{abstract}

In order to understand the socio-political position of Muslims in Norway and prevailing value discourses among citizens who identify themselves as Muslims, it is necessary to bear in mind some special features of Norwegian society such as the egalitarian tradition, the welfare state legacy and the strong position of feminism in Scandinavia. ${ }^{1}$

Another influential feature is the still prevailing state church system which implies that Muslim organizations-like other registered faith communities-receive financial support from the state.

\footnotetext{
${ }^{1}$ In the field of education, the egalitarian 'one school for all' system seems so far to be supported by the Muslim community. Reflecting both Muslims' priorities, relatively strict policies towards religious schools and the fact that the issue of Muslim private schools is a controversial one in general society, there are presently (2012) no private Muslim schools in the country. Cf. 'Sier nei til muslimske skoler', Aftenposten 17 April 2012.
} 
Norway may also boast of a relatively strong culture of dialogue, at least between leaders of the faith communities. The climate in public debates about Islam, however, is markedly different-influenced by Islamophobic discourses in general society and confrontational identity discourses in some Muslim circles.

In tune with the general aim of this volume - to investigate the dynamic relationship between Islamic and public institutions and values (cf. the introductory chapter) - I will try to elucidate some relational aspects of Muslim identity discourses in Norway, as they have developed in the framework of the welfare state and in organized dialogue with Christian and Humanist partners.

\section{Islam in Norway}

Muslims in Norway either trace their Norwegian roots back to labour immigration from the 1970s, or they have come as refugees and asylum seekers from the late 1980s onwards. An estimate built on figures from 2008 indicated that at that time more than 160,000 Norwegian residents were Muslims by cultural background (Daugstad and Østby 2009). With additional immigration during the last few years, this means that Muslims (counted by cultural background) constitute perhaps 3.5\% out of a total population of 5 million.

The estimated figure (in 2012) of at least 180,000 'cultural Muslims' should be compared with the more exact number of registered Muslims in Norway. In 2012, 112,000 (about $60 \%$ of those with a Muslim background) had signed up for membership of a Muslim religious organization. Approximately half of these are resident in Oslo, which means that at least $8 \%$ of Oslo's population (total population: 590,000 ) are now members of a Muslim organization. The percentage of Oslo residents with a Muslim background is obviously much bigger. A survey among youth in Oslo, conducted in 2006 among 15-17 year old school pupils, showed that $17.6 \%$ stated Islam as their religion; up from 13.2\% in 1996 (Vestel and Øia 2007:162f). Concentration in certain urban areas implies that certain districts of Oslo have a majority of Muslim pupils in primary schools. 
But how should Muslims be counted? Underlying the different types of figures cited above (Muslims by background or membership) one might find different perceptions of what constitutes a religious identity: Is it (as in traditional societies) a matter of cultural belonging, or (as in modern societies) of organizational affiliation and of personal choice?

All these dimensions of religion - as cultural heritage, as faith community, as personal conviction - should be borne in mind when discussing the social role of a particular religion and its adherents in a given context. In what follows, the main emphasis will be on organized expressions of Islam in Norwegian society, although cultural and individualized aspects of religion will also be considered.

Among Muslims who first came as labour immigrants and have later enjoyed family reunion and had children in Norway, by far the most numerous group are those with a Pakistani background numbering 32,700 in 2012. In the same year, Turks made up 16,700 and Moroccans 8600 of the immigrant population. Among those who have come as refugees and asylum seekers, the Somalis $(29,400)$ and the Iraqis $(28,900)$ were the most numerous groups, followed by Iranians $(17,900)$, Bosnians $(16,300)$, KosovoAlbanians $(13,700)$ and Afghans $(13,200){ }^{2}$

The combined effect of the variety of Islamic immigrants and organizational impetuses from Norwegian society (including the possibility of financial grants; see below) give a high degree of intra-Muslim pluralism. Along with organizational pluralism, one may also observe the competing patterns of folk Islam versus different articulations of normative Islam. Whereas representatives of folk Islam have often tried to retain the totality of their inherited cultural conventions and religious convictions, the second generation has felt the need to redefine the relation between culture and religion. Many of them take pains to distinguish between 'culture' and 'religion', in order to articulate an Islamic identity which is both universal and amenable to re-contextualization. As we

\footnotetext{
${ }^{2}$ Numbers from Statistics Norway, http://www.ssb.no/emner/02/01/10/innvbef/tab-2012-04-26-04.html
} 
shall see in the following, some striking examples can be cited of the younger generation of Muslim leaders in Norway identifying central 'Norwegian' values as 'Islamic'.

The growth in Muslim organizational life has largely taken place from the late 1980s and onwards. Whereas in 1980 no more than $10 \%$ of those with a Muslim background had actually organized themselves as Muslims in Norway, the relative numbers rose to $50 \%$ in 1990 and (as we have seen) perhaps 60\% in 2012.

Muslim congregations can now be found in all Norwegian counties, with the largest concentration around Oslo. Among the 40 or so Muslim prayer rooms in Oslo, most of which are located in converted flats, factories or office premises, four mosques are purpose-built — all of them by Norwegian-Pakistani organizations. This implies the Oslo is home to more purpose-built mosques than any other Nordic city.

Most Muslim organizations in Norway are still ethnically based, but this is slowly changing. From the mid-1990s, separate youth and students' organizations have been formed, fully independent of the national background of the young Muslims' parents (Jacobsen 2002). Separate women's organizations have also been established, and in 1993 the Islamic Council of Norway was formed as a national umbrella organization now comprising the majority of Sunni Muslim congregations in Norway. The political authorities have gradually established a regular communication with the Islamic Council, and from 2007 the Council also receives a financial grant from the government.

In terms of religious practice, there is still a lack of reliable sociological data. However in 2006, 27\% of the Muslim respondents said in a Gallup opinion poll that they attended 'religious ceremonies together with others' on a monthly basis or more frequently. ${ }^{3}$ The

\footnotetext{
3 'TV2: Holdninger til integrasjon og internasjonale konflikter blant muslimer i Norge og den norske befolkningen generelt', TNS Gallup, Politikk \& Samfunn, April 2006 (http://pub.tv2.no/multimedia/TV2/archive/00248/TNS_Gallup_-_muslim_248757a.pdf).
} 
opposite figure of $31 \%$ stating that they never took part in such activities indicates a high degree of polarization among cultural Muslims when it comes to mosque affiliation and religious practice. In a different survey of immigrants' living conditions from 2005-6, in which different groups were asked to state the importance of religion in their lives (Tronstad 2008), the Pakistani and Somali group are found at the higher end, followed by the Turks, with Bosnians and Iranians at the other end of the spectrum and Iraqis somewhere in the middle. When asked how often they took part in religious meetings organized by faith communities, Pakistanis, Somalis and Turks again placed themselves at the top with Bosnians and Iranians at the bottom end.

As regards methodological approaches to Muslim attitudes and practices, the basic question is of course whether Muslim pluralism can really be captured by means of organizational mappings or survey questions about collective practices. Jacques Waardenburg notes that in post-modern societies, religious identities have become increasingly personalized and plural in nature:

Leaving apart the influence of political and economic power, already the complexity of modern societies means that people now participate in several identities which are often juxtaposed to each other rather than being put in an hierarchical order (Waardenburg 2000: 159).

Immigrated Muslims participate in the post-modern, Western reality of plural identities. Whereas some scholars tend to focus on the problems that young Muslims in Norway face when torn between seemingly irreconcilable expectations, Sissel Østberg has focused on young Muslim believers' well developed competence to handle what she terms 'an integrated plural identity' (Østberg 2003). Plural identity implies the simple fact that irrespective of religious belonging, people share (or are divided by) such factors as gender, cultural affiliations, musical preferences, a passion for football, or more importantly, political convictions that run right across cultural and religious divides. 


\section{Political responses and legal rights}

In terms of political responses to the growing Muslim presence in Norway, until the late 1990s government representatives were reluctant to relate directly to Muslim organizations-giving priority instead to ethnic organizations. A more direct politics of recognition towards the Muslim faith communities was introduced by the Christian Democrat-led government, symbolized by the first visit by a Prime Minister to a Norwegian mosque in August 1999. It was this politics of recognition that was followed up by the Social Democrat-led government during the Danish cartoon crisis in 2006 and in the aftermath of the 22 July 2011 terror attack and massacre, symbolized by a number of formal visits to mosques by the Prime Minister and the Minister of Foreign Affairs.

Thus the relationship between the Muslims and larger society has increasingly become a matter of public concern, realized as such also by the political authorities. Predictably, the authorities have been criticized by feminists, neoconservatives and some selfdesignated 'secular Muslims' for privileging the established Muslim leadership in these conversations -strengthening their position as (not necessarily elected) spokespersons.

In terms of legal arrangements, a multiculturalist recognition of the interests of religious communities is symbolized by a clause in the Law about Equality of Sexes (from 1978), which until recently made exemptions for 'internal affairs in the faith communities'. An amendment from 2010 implies that the faith communities will have to argue from case to case why it is deemed necessary to treat women and men differently in relation to specific religious functions.

Since 2000, there has been a growing consensus between religious leaders and mainstream politicians around the slogan 'an actively supportive politics of religion' which reflects a positive recognition of the faith communities' contribution to larger society and a rather strong affirmation of their autonomy. However, a more value-based politics of religion has also been called for by some left-wing politicians, in particular feminists who in the question of gender equality have opted to put some more pressure 
on the faith communities - by tightening the conditions for receiving financial grants from public budgets (Leirvik 2009).

In financial terms, the survival of the state church system implies that the Lutheran Church of Norway (which in 2012 comprised 77\% of the population) is almost fully financed by public budgets. Paradoxically, this system is beneficial for the other faith communities as well. By virtue of compensatory measures that were introduced in 1969, every faith and (from 1981) life stance community that registers itself is entitled to exactly the same amount per member in state and municipal support as the Church of Norway receives.

The logic of the system is that as long as state church budgets are financed by the general income tax, taxpayers need to be reimbursed in some way or another in order to avoid discrimination. The uniqueness of the system lies in the fact that the reimbursement goes to the faith communities and not to individual taxpayers. This means that in financial terms, not just Lutheran Christianity but also other Christian churches, other religions and the Humanist Association may be referred to as 'established faiths' with state support in Norway. Muslims in Norway have often made the point that this rather unique system has enabled them to enjoy a relatively high degree of freedom vis-à-vis Muslim interest groups abroad. The system gives also, of course, a rather strong incentive for the mosques to have Muslims signing up for membership.

Whereas Sweden introduced 'changed relations' between state and church in 2000, Norway, Denmark and Iceland retain some sort of a state church system. In 2008, the Parliament took an important step towards disestablishment, through a consensus which resulted in constitutional amendments in May 2012. The consensus includes a provision that all faith communities will continue to be financially supported by the state (although the size of this support - to the Church of Norway and hence to other faith communities — will probably become a matter of annual budget discussions). 
In current debates over the state church system, the Muslims in Norway have generally taken a less radical view than the Humanist Association and the non-Lutheran Protestant churches which have both argued full disestablishment. Muslim leaders have in the main opted for more moderate reforms. Their arguments have varied between a concern for morality supported by public religion, fears of mounting secularization and the financial benefits of the current system. In tune with a favourite argument among the Social Democrats, Muslim politicians of such leanings have also expressed the view that the state should exercise 'some control' of religious practices. ${ }^{4}$

\section{Political inclinations and endorsement of social democratic values}

At the level of political representation, most parties now have a number of relatively well-known representatives of Muslim background. Since 2001, three young Muslim women and two men have been elected as (regular or deputy) Members of Parliament, representing different parties and contributing symbolically to a more religiously pluralist image of political life in Norway. Even the Christian Democrats have boasted of Muslim voters who sympathize with their traditional 'family values' and their restrictive policy regarding distribution of alcohol, as well as their understanding attitude towards making religious claims in the public sphere.

As indicated by recent polls, however, the vast majority of Muslim or non-Western immigrant voters seem to support the social democrat and socialist parties. In the 2006 survey of attitudes referred to above, $83 \%$ of the Muslim respondents (against $45 \%$ of the control group representing the general population) said that they had given their vote either to the Labour Party (the Social Democrats) or to the Socialist Party in the latest parliamentary elections. Corresponding figures from a survey in 2007, in which $82 \%$ of non-Western immigrants revealed the same preferences, ${ }^{5}$ indicate that socialist preferences may reflect immigrant interests in general rather than Muslim sensibilities specifically. It is interesting to note, however, that some Muslim leaders in Norway

\footnotetext{
4 ،...mens muslimene vil ha statlig kontroll', Klassekampen, 6 January 2006.

5 'Innvandrere til AP og SV', Aftenposten 30 August 2007.
} 
have referred to the Norwegian welfare state (which is generally associated with social democracy) as coming very close to Islamic ideals. For instance, in 2005 Shoaib Sultan (who became later the General Secretary of the Islamic Council) stated that

Many Muslims see today's welfare state in Norway as closer to the Muslim ideal state than many countries in the Muslim world, and Norwegian Muslims want to keep the Norwegian state as it is (Sultan 2005:90, my translation).

Similar attitudes were expressed by a selection of Norwegian-Pakistani respondents who were interviewed in 2010 in connection with a qualitative research project on religious commitment and social integration, by utterances such as 'The Norwegian welfare state is Islam in practice' and 'Norway is more Islamic than Pakistan' (Døving et al. 2011: 19).

A quantitative survey among pupils in upper secondary school in Oslo in 2009 yielded similar results. The survey showed that Muslim youth were more inclined than their Christian or non-religious peers to give strong support to welfare state values such as income leveling $(51 \%$ of the Muslims against $30 \%$ of the Christians and the nonreligious) and efforts towards social equality in general (68\% of the Muslims against $45 \%$ the Christians and the non-religious; Botvar and Wyller 2009).

The cited tendency among Norwegian Muslims to associate values of social equality and the welfare state with Islamic values could be interpreted in at least three different ways. (1) It could be taken as an expression of enlightened self-interest among immigrant groups who have benefited from welfare state arrangements in the process of integration. (2) It may reflect dominant discourses in Norwegian society and the fact that welfare state values (although increasingly contested) are seen almost as a source of national pride, across cultural and political divides. (3) It could also be seen as a reflection of a more general tendency among Muslim reformers to associate the Scandinavian welfare systems with Islamic values. An example can be found in the book Islam - the Misunderstood Religion which was published in Arabic in 1964 by 
Muhammad Qutb, a prominent member of the Muslim Brotherhood. In view of the Islamic ideal of social justice, Qutb says, 'the Scandinavian states have in this connection come closer than any other state in the world-to a realisation of some aspects of Islam' (Qutb 2000: 77, cf. Gardell 2005: 120f. who claims that with Muhammad Qutb, a social democratic interpretation of political Islam was made explicit). The cited interpretations are not mutually exclusive and the endorsement of welfare state values demonstrates how Muslim spokespersons express their commitment to Islamic values in terms of perceived common (even emblematic) values in Norwegian society such as social equality and-as we shall see below-equality between the sexes.

\section{The centrality of women's issues}

In the Scandinavian context, the aim of gender equality has traditionally been a central part of social democratic policies and welfare state arrangements, resulting in a kind of 'state feminism' which corresponds with high cultural awareness about gender (in)equality in Norwegian society. The question of gender equality has also become the focus of immigration-related controversies. Stereotypes between Muslims, Christians and secular citizens in the West are often related to the perceived status of women-as objectified victims of either a 'permissive' or a 'patriarchal' culture (Grung 2004). Critical voices of either liberal or neoconservative leanings regularly attack Muslim cultures and Islam as a religion which is inherently oppressive of women. From the mid-1990s, most media discussions on Islam in Norway have been focused on womenrelated issues such as arranged or forced marriages, the question of whether a Muslim woman may marry a non-Muslim man, female genital mutilation, and the headscarf (which is constantly debated but not banned, except in a few private enterprises and in the police).

On the other hand, Muslims seem also to be influenced in a more affirmative manner by gender models in Norwegian society. Several young women of Muslim background have become publicly known for their vociferous protest against cultural practices 
associated by them with the religion of 'Islam'. They are addressing women's issues not from the outside, but from within the Muslim communities.

A striking example of the way in which young Muslim leaders may identify Scandinavian gender equality values with Muslim convictions can be found in a newspaper article from 2009 entitled 'Muslims in the process of change' by the then leader of the Muslim Student Association in Oslo, Bushra Ishaq. Here she stated:

The Muslim Nora ${ }^{6}$ raised in Norwegian schools is now breaking free from traditional attitudes. We raise a struggle to realize ourselves as independent individuals, as Norwegian girls who have been taught to fight for gender equality. Were it not for the fundamental influence of Norwegian culture and the values of the welfare state, the emerging Muslim feminism would not be a fact (Ishaq 2009, my translation).

Some young women representing an 'emerging Muslim feminism' in Norway have experienced dramatic conflicts with their families and been engaged by feminist activists and the media to record statements from Muslim leaders by the use of hidden microphone or camera. The most dramatic episode occurred in the autumn of 2000 when a young woman of Somali background, equipped with hidden camera by a commercial TV station, revealed that a number of male African Muslim leaders either supported female circumcision or did not (as it seemed) clearly oppose it. As an immediate result, the then president of the Islamic Council-a highly respected Muslim of Gambian background who has also a long record in Christian-Muslim dialoguechose to resign. ${ }^{7}$

It was against this background that Lena Larsen - a female convert to Islam and also a dialogue- and human rights activist—was elected as the new president of the Islamic

\footnotetext{
${ }^{6}$ A reference to the character Nora in Henrik Ibsen's play A Doll's House.

${ }^{7}$ Cf. the retrospective analysis by Inger Anne Olsen in Aftenposten 9 November 2002 ('Var rikets tilstand sånn som vi trodde?').
} 
Council, an event of almost historic dimensions. In 2002, the central mosque in Oslo elected a young female student, Amber Khan, as their new spokesperson to the public. In addition, female activists have long played central roles in Muslim youth organizations. As indicated above, the majority of Muslim Members of Parliament in Norway have also been young women.

However, the cited examples of female leadership in Muslim organizations are still episodes and the overwhelming majority of board members in Muslim organizations remain male. A survey in 2010 revealed that less than $3 \%$ of the mosques' board members and public spokespersons were women. ${ }^{8}$ The cited examples still illustrate how Islam is being inculturated in a Nordic environment marked by strong values of gender equality.

Although feminist impetuses may be unusually strong in Norway, it is also clear that female activists in Norwegian Islam embody a much wider tendency of Islamic-style feminism in Europe which Anne-Sofie Roald has documented and analysed in her book Women in Islam. The Western Experience (Roald 2001). It is hard to prophesy, however, which tendency will have the upper hand in the years to come. When Mohammad Hamdan (an immigrant of Arab background) was elected as the new president of the Islamic Council after Lena Larsen's term in office was terminated in 2003, he asserted that Islam supports the rights of women to equal participation in society (in this respect, they can learn from their Norwegian sisters) but reiterated also the traditional claim that Western women have something to learn from the priority that Muslim women will always give to family values. ${ }^{9}$

In sum, the above developments imply that the question of women in Islam is not really a debate between the Muslims and Norwegian society in general. It is just as much an intra-Muslim debate, in which young Muslim women-inspired both by 'normative Islam' and Scandinavian values — increasingly set the agenda.

\footnotetext{
8 ‘126 moskéer - én kvinnelig leder’, Vårt Land 20 January 2010.

9 'Norske kvinner kan lære av muslimene', Dagsavisen, 7 March 2003.
} 


\section{Relational perspectives: popular debates and interreligious dialogue}

The question of Norwegian Muslims' value orientation and the delicate balance between (confrontational or defensive) identity politics and open-ended dialogue can only be meaningfully described and analysed in a relational perspective. In the general public, inclusive attitudes have long competed with mounting anxiety towards Islam and Muslims. According to the survey underlying the so-called 'Integration barometer' (IMDi 2009), 84\% of the respondents thought that the authorities should not further facilitate Muslim religious practices in Norwegian society. The fact that $72 \%$ expressed a sceptical attitude towards religious organizations in general indicates that these figures might have just as much to do with secularism as with Islamophobia. In the same survey half of the respondents opposed the building of mosques in Norway, and a clear majority also opposed the wearing of headscarves in public.

In the 2008 report by the European Commission against Racism and Intolerance, Norway was for the first time urged to take action against mounting Islamophobia. The report

strongly recommends that the Norwegian authorities monitor the situation as concerns Islamophobia in Norway and take swift action to counter any such manifestations as necessary. It encourages the Norwegian authorities to cooperate with representatives of the Muslim communities of Norway in order to find solutions to specific issues of their concern. ${ }^{10}$

The attitude of Christian leaders has (as a rule) been markedly different from the cited Islamophobic tendencies in the general public. Interreligious dialogue is commonly regarded as rather well established in Norway and was institutionalized earlier than in the other Nordic countries. ${ }^{11}$ Three regular forums deserve special mention: the bilateral

\footnotetext{
${ }^{10}$ ECRI Report on Norway, 2008 (published 2009), paragraphs 91-92, http://www.coe.int/t/dghl/monitoring/ecri/Country-by-country/Norway/NOR-CbC-IV-2009-004ENG.pdf, accessed 2 May 2010.

${ }^{11}$ For a general presentation of interfaith dialogue in Norway, see Leirvik 2001 and 2003.
} 
Contact Group for the Church of Norway and the Islamic Council (established 1993), ${ }^{12}$ the multilateral Council for Religious and Life Stance Communities (established 1996) ${ }^{13}$ and the Council's international wing known as the Oslo Coalition on Freedom of Religion or Belief. ${ }^{14}$ Whereas the Contact Group came about as the result of an invitation from the majority church (the Lutheran Church of Norway), the Council for Religious and Life Stance Communities grew out of minority protest against the new and compulsory subject of religious and ethical education in public schools whichwhen announced in 1995-was felt by Muslims, Jews, Buddhists and the Humanist Association to be strongly dominated by Christian majority interest.

The Council for Religious and Life Stance Communities coordinates the faith communities' interest vis-à-vis the authorities, works for mutual respect between different faiths and life stances, and addresses social and ethical issues of common concern. It is important to note that the Humanist Association has been a member of the interfaith council from the beginning and has also taken actively part in other multilateral dialogue projects. This has challenged both religious and non-religious dialogue partners to seek a faith-transcending language for one's commitment (cf. Habermas' reflections on the requirement to translate religious concerns into a generally accessible language, as discussed in the introductory chapter of this issue). The titles of two formative interfaith dialogue projects in the 1990s are indicative of the search for a common ethical, human-rights oriented language which has also put its mark on Muslim discourses in Norway: 'Communal Ethics in a Multicultural Norway' (Eidsvåg and Leirvik 1993) and 'Religion, Life Stances and Human Rights in Norway' (Eidsvåg and Larsen 1997).

Although the mentioned projects received some support from the authorities, they were initiated by interfaith activists. It should be noted that none of the regular dialogue forums listed above have come about because of government initiatives but they are

\footnotetext{
${ }^{12} \mathrm{http} / / /$ folk.uio.no/leirvik/Kontaktgruppa.htm

${ }^{13} \mathrm{http}: / /$ www.trooglivssyn.no/

${ }^{14}$ http://www.oslocoalition.org/
} 
fully the result of civil society activism. State support for such activities is actually a relatively recent phenomenon in Norway (unlike for instance Great Britain and Germany, where the authorities have sought more actively to establish 'partnership' and 'dialogue' with Muslim faith communities in particular).

As for the bilateral Christian-Muslim Contact Group, the group's early agenda was much focused on Muslim minority concerns in Norway-for instance as regards religion in school and anti-Islamic tendencies in public debates. But over the years, the precarious situation of Christians in some Muslim countries has become an equal concern - as expressed in joint statements such as 'Stop the violence against Christians in Pakistan' (2009). ${ }^{15}$ In recent years, the group has also shown a growing concern for individuals under pressure - as expressed in a milestone statement in 2007 on the inviolable right to conversion (which also caught international attention) ${ }^{16}$ and another statement in 2009 against violence in close relationships. ${ }^{17}$

From the scene of Christian-Muslim dialogue in Norway, several remarkable expressions of inter-religious understanding and solidarity could be cited - in concrete opposition to more confrontational tendencies. In cultural and political debates about Christianity and Islam, church leaders have in general defended Muslim minority rights and protected their integrity against populist assaults. On the confrontational side, the influential right-wing populist party Fremskrittspartiet ('The Progress Party') has increasingly singled out 'Islam' as an enemy to Norwegian society and to Christianity. In recent years, the Progress Party has attracted more than $20 \%$ of the voters, in elections and polls. Their support dropped to $11.5 \%$ in the 2011 local elections but rose to $16.3 \%$ in the parliamentary elections in 2013, after which Fremskrittspartiet was invited to form a new government together with the larger Conservative Party (Hфyre).

\footnotetext{
15 'Stopp volden mot kristne i Pakistan', kirken.no 13 August 2009, http://www.kirken.no/?event=showNews\&FamID=93378

16 Joint Declaration on the Freedom of Religion and the Right to Conversion, kirken.no 22.08.2007, http://www.kirken.no/english/news.cfm?artid=149142

17 'Norwegian Muslims and Christians say no to domestic violence', kirken.no 09.11.2009, http://kirken.no/english/news.cfm?artid=265872.
} 
Since the end of the 1980s, the Progress Party has repeatedly warned against 'Islamization' during their electoral campaigns, most recently in 2009 when the party suggested that new and covert forms of Islamization (snikislamisering-'creeping Islamization') could be identified in Norway. Similar Islam-critical stands have been voiced by groups associated with the New Christian Right, although their warnings against Islamization have regularly been countered by mainstream Christian leaders (Leirvik 2011).

Although the anti-Islamic rhetoric of Anders Behring Breivik, the Norwegian 22 July terrorist, shares a family resemblance with populist warnings against 'Islamic occupation' of Europe, his brutal violence is of course of a singular character. It should be noted, however, that the 2012 report of the Norwegian Police Security Service (PST) warned against the potentially violent consequences of the enemy images produced by anti-Islamic agents who formally dissociate themselves from acts of violence. ${ }^{18}$

In 1997, Christian leaders of all confessions and quite different theological tendencies joined hands with the Muslim communities and warned publicly against the hostile images of Islam produced by populist politicians. ${ }^{19}$ A similar ecumenical alliance 'against Islamophobia and the defamation of Muslims' was mobilized in 2004, when Charismatic leaders joined the mainstream churches in a protest against a speech that Carl I. Hagen (the then chairman of the Progress Party) gave in New Christian Rightoriented congregation in the city of Bergen. In this speech, which was widely publicized, he launched a harsh attack on the Prophet Muhammad as a warlord, implying that Islam is an inherently violent religion. His view of Muhammad and Islam was later corroborated in his autobiography, in which he characterizes Muhammad as 'the warlord, assailant and abuser of women ... who murdered and accepted rape as a means of conquest' (Hagen 2007: 539, my translation).

\footnotetext{
18 ‘Åpen trusselvurdering 2012’, Politiets sikkerhetstjeneste 2012.

19 'Kristenledere mot økt muslimfrykt', Christian Council of Norway press release 29 August 1997, http://folk.uio.no/leirvik/tekster/Hyrdebrev1997.doc
} 
The tension between confrontational tendencies - as headed by the Progress Party, certain Charismatic groups and neoconservative activists - and dialogical trust-building was strikingly demonstrated during the cartoon crisis in 2006. Whereas in Denmark the liberal-conservative government simply refused to speak to Muslim organizations during the crisis (insisting that religion is a private matter), in Norway the social democrat-led government leaned on established structures for Christian-Muslim dialogue and engaged the Islamic Council as a partner in crisis management.

In Denmark, it was the mainstream newspaper Jyllands-Posten that commissioned and published the cartoons. In contrast, in Norway the cartoons were republished by a relatively small magazine of the New Christian Right, Magazinet, who was also known for its sympathies with the Progress Party (Leirvik 2011). In its framing of the republication, the magazine also reproduced the usual stereotypes of Islam as a religion prone to violence. Straight after the republication, Christian and Muslim leaders came together and issued a joint statement in which they affirmed freedom of expression as a fundamental right but warned also against deliberate provocation against religious feelings. ${ }^{20}$ By mediation of Christian Democrat politicians, an official event of reconciliation was staged between Magazinet's editor Selbekk and the Islamic Council, which publicly forgave him and promised to protect him against threats that he had received to his life. In political recognition of this lightly forced effort at ChristianMuslim reconciliation, the event was presided over by representatives of the government. And with financial backing from the government, the Islamic Council arranged delegation trips together with Christian leaders to the Middle East and Pakistan, in order to explain the Norwegian culture of dialogue (Leirvik 2011).

Although the cartoon crisis thus ended in a series of 'dialogical' events, what took place between religious leaders and the government might not be representative of public sentiments. In the wake of the cartoon crisis and its relatively peaceful solution in

\footnotetext{
20 'Religious leaders in Norway denounce the publication of caricatures', kirken.no 03.02.06, http://www.kirken.no/english/news.cfm?artid=75655
} 
Norway, media debates have increasingly taken a critical approach to the notion of dialogue, implying that interreligious dialogue implies a harmonizing approach that conceals real differences and corroborates established power structures in the religions.

Interfaith activists, on the other hand, would point to the fact that the Contact Group between the Church of Norway and the Islamic Council has increasingly addressed highly sensitive issues such as the position of women in the religious communities, the issue of homosexuality, and the question of conversion. Concerning the issues of conversion and violence in close relationships, a shared commitment has developed regarding the need to protect vulnerable individuals against religiously or culturally legitimized abuse, as can be seen from the aforementioned joint declarations from 2007 and 2009.

\section{Radical Islam $^{21}$}

As for political Islam, more or less Islamist movements in Pakistan (Jamaat-i islami), Turkey (Milli Görüs) and the Arab world (the Muslim Brotherhood) have long been represented in Norway, by affiliated organizations or followers. Although each of these organizations has its own agenda, their European profiles may differ considerably from that of their mother organizations. It is also a fact that organizations and mosques representative of 'moderate Islamism' are often more active in interfaith enterprises than their more traditionalist counterparts (cf. Vongraven Eriksen \& Mårtensson, in the present issue).

Until recently, radical Islamist movements such as Hizb al-Tahrir (active in Denmark) have not been able to seize an organizational foothold in Norway. This does not mean

\footnotetext{
${ }^{21}$ This paragraph ('Radical Islam') deals with Salafist and militant Islamist tendencies among Muslims in Norway. After the present article was finalized in December 2012, one book and several articles have been published about the mentioned developments, with particular reference to the organizations Islam Net and The Prophet's Ummah. See Lars Akerhaug: Norsk jihad. Muslimske ekstremister blant oss (Oslo: Kagge 2013); Marius Linge: 'Den konservative vekkelsen. Om IslamNet, Profetens Umma og salafismens fremvekst i Norge' (Samtiden 4: 2013, pp. 38-53); Sindre Bangstad and Marius Linge: 'IslamNet - puritansk salafisme i Norge'(Kirke og Kultur 4: 2013, pp. 254-272) and Ulrika Mårtensson's article ('Harakî Salafism in Norway: 'The Saved Sect' Hugs the Infidels') in the present issue.
} 
that radical or extremist positions are not represented among Norwegian Muslims. For instance, accusations were put forward in 2002 that Mullah Krekar, a leader of the radical Islamist movement Ansar al-Islam in Iraqi Kurdistan, had maintained his militant activities with Norway as a safe haven. However, in 1997 his group of radical followers had been asked to leave the main Arab mosque in Oslo (Rabita, a mosque of Muslim Brotherhood inspiration). And in May 2003, when it was announced that Norwegian institutions abroad were put on the list of potential targets for al-Qa'ida, it was clear from the immediate reaction of the Muslim leaders who were interviewed that they instinctively identified themselves as Norwegians and felt threatened on a par with their Christian or secular humanist co-citizens. ${ }^{22}$

However, individual examples of more confrontational attitudes can also be cited. In 2002, the convicted criminal Arfan Bhatti was quoted in an interview that after a bornagain experience in the prison, 'I now live for Islam, and hate Norwegian values ... I have so much sympathy for my Muslim brethren. We Muslims have been and still are suppressed by Jews, Hindus and Americans. ${ }^{23}$ In 2008, the same person was accused of having instigated gunshots against the synagogue in Oslo and for planning terrorism (he was acquitted of the latter charge). Two years later, Arfan Bhatti turned up as the coplanner of a demonstration against another caricature of Muhammad, re-published by the liberal newspaper Dagbladet. It was in this demonstration that 'radical Islam' got an identifiable face for the general public, when one of the appellants (Mohyeldeen Mohammad) warned against terrorist attacks against Norway unless the country gave up its 'crusade' against Islam (expressed by Norway's warfare in Afghanistan and Iraq and by an alleged alliance with the media aimed at defamation of Muslims). Interestingly, the appellant also accused the Islamic Council of having accepted a deplorable attitude of 'compromise' with the authorities (Larsen 2010). Both in 2006 and 2010, the Islamic Council advised against demonstrations against the caricatures, displaying thus a more

\footnotetext{
${ }^{22}$ See interviews with Muslim leaders in Verdens Gang ('Vil angi muslimske terrorister - imamene vil verge Norge') and Dagbladet ('Vi føler oss også truet'), 22 and 24 May 2003.

23 '- Jeg lever for islam, og hater norske verdier', Dagbladet 26 August 2002.
} 
negotiation-oriented approach to inter-group conflicts. The fact that large numbers of independent (mostly young) Muslims nevertheless took to the streets in more radical acts of protest seems to indicate that for the Islamic Council the price of political recognition has been intra-Muslim discord—although by a radical minority.

Then in the autumn of 2012 , the more radical minority went public as the newly founded organization 'The Prophet's Ummah' which in September staged a demonstration against the film Innocence of Muslims, invoking Osama bin Laden as a hero of Islamic resistance and rallying some 100 participants outside the US Embassy (against 6000 in a peaceful meeting held simultaneously in Oslo by the Islamic Council). The militant demonstrators included the previously mentioned Arfan Bhatti and Mohyeldeen Mohammad, joined by a newcomer to the radical scene, Ubaydallah Hussain, who later in the autumn was detained for having threatened named journalists and the Jewish community. ${ }^{24}$

Among Muslim youth, the fastest growing organization over the last years has been Islam Net, a markedly value-conservative organization with Salafist inspiration and apologetic orientation, which also seeks to reform traditional Muslim practices which are considered to be un-Islamic (including forced marriages). Unlike The Prophet's Ummah, Islam Net does not have a militant profile. The organization regularly stages large conferences which attract a considerable number of Muslim teenagers and young adults. International guests include renowned preachers such as Abdur-Raheem Green, Hussein Yee and Yusuf Chambers. ${ }^{25}$ Although Islam Net's gatherings are called 'peace conferences' (probably inspired by Zakir Naik's 'Peace TV'), representatives of the organization take a confrontational attitude against 'others' and markedly countercultural stands in issues such as gender relations, homosexuality and the death penalty. ${ }^{26}$

\footnotetext{
24 'De er norske militante islamister', Morgenbladet 16 November 2012 and 'Islamistisk samling', Aftenposten 15 December 2012.

${ }^{25} \mathrm{http}: / / \mathrm{www}$.islamnet.no/

26 'Mener Islam Net-sjef er 'uegnet som leder' etter dødsstraff-uttalelser', VG 04.09.11.
} 
The radical-militant and conservative-apologetic profiles of the Prophet's Ummah and Islam Net respectively are markedly different from that of 'Young Muslim', another influential Muslim youth organization which (confluent with majority values?) seeks to 'contribute to the development of competent and well-integrated youth who is just as confident in their Muslim and Norwegian identity'. ${ }^{27}$

At the everyday level, success stories of integration expressed through Muslim identification with mainstream Norwegian values compete with anti-Western sentiments and sexist/racist attitudes against white women-as expressed both by frustrated newcomers and traditionalist members of the first generation of immigrated Muslims.

In Norway as elsewhere, it is hard to decide what kinds of tendencies prevail in Muslim identity discourses that are less public. Whereas after 9/11 individual school teachers reported that some of their pupils (in particular, young boys) had expressed their secret admiration of Osama bin Laden, others pointed to the fact that Muslim students seemed to face an identity crisis when confronted with terrorist acts perpetrated in the name of 'Islam', denying altogether that such acts could possibly have anything to do with Islam as they know it (cf. Leirvik 2004). An interview-based investigation from 2010 demonstrates that the mounting discourse about 'radical Islam' and 'radicalization' in Norwegian and other European media contributes more than anything else to further alienation of Muslim youth who seek a delicate balance between identification with mainstream Norwegian values, perceived tenets of Islam, and a sense of international solidarity with other Muslims under pressure (Kristensen 2010).

\section{Between identity politics and dialogue}

In conclusion, the image of the Muslim population in Norway is becoming more and more complex. A wide array of cultural identities competes on the one hand with a growing sense of Norwegianness (in tune with mainstream value discourses in society) and on the other with Islamic identities which function as a form of 'symbolic ethnicity'

\footnotetext{
${ }^{27}$ www.ungmuslim.no
} 
across national identities (Kastoryano 2004:1250ff). Minority discourses with a defensive touch among ordinary Muslims compete with a relatively strong commitment to interreligious dialogue among Muslim leaders, and the emerging Muslim establishment seems already to have fostered a more radical opposition.

As for the prospects of inter-group dialogue, one important arena deserves special mention, namely public schools and the subject of religious education that have been introduced at both primary and secondary levels. As mentioned above, Muslims have in general been quite supportive of the egalitarian 'one school for all' system in Norway. However, the subject of religious education, which was made compulsory in 1996 for pupils in primary and lower secondary school, has created some tension. Muslims, other religious minorities as well as the secular humanists have criticized the subject for being too much dominated by Christian majority interest. Minority complaints were backed by the UN Human Rights Commission in 2004 and by the European Court of Human Rights in 2007, forcing Norway to revise the name of the subject (it is now called Religion, Life Stances, and Ethics), its curriculum (which is now less dominated by Christianity) and the objects clause for the school system in general (which was reformulated in 2008 in slightly more inclusive ways with regard to religion). Although there is still some discontent with the subject, there are many indications that it has now become more acceptable to the minorities - so that it may function according to the intention of providing an arena for interreligious learning and dialogue training.

The example of religious education in school as a possible arena for dialogue indicates once more that the issue of future Muslim developments is a relational question, in which majority and minority interest will have to strike a delicate balance. As I have tried to demonstrate, however, 'minority' is not necessarily a category that all Muslims would like to use as their prime self-identification. The cited examples of how leading Muslims identify 'Islam' with dominant values in Norwegian society, along with a desire to contribute constructively to a solidarity-based society, testify more to a Norwegian contextualization of Islam than to minority discourses and transnational identity politics. 'Public Islam' (cf. the introductory chapter in this volume) in the 
Norwegian context seems thus to be largely confluent with emblematic values in larger society, although what is expressed in public, by more or less established spokespersons, is certainly not the entire truth about value politics among Muslims. As indicated, the tendency towards a dialogue-oriented 'Norwegian Islam' is not the only one to be observed. Dialogue initiatives have developed in competition with confrontational identity politics in both the Muslim minority and the ChristianHumanist majority population.

Which tendency will have the upper hand in the future depends both on structural questions of social cohesion (which include the integrating function of welfare society values) and of the agency of dialogue activists who are committed to making a difference by doing what does not come by itself.

\section{References}

Ahlberg, Nora, 1990: New Challenges-Old Strategies. Themes of Variation and Conflict among Pakistani Muslims in Norway. Finnish Anthropological Society, Helsinki.

Botvar, Pål Ketil and Trygve Wyller, 2009: “Unge religiøse har radikale ideer”, Aften 7 April 2009: 14.

Daugstad, Gunnlaug and Lars Østby, 2009: "Det flerkulturelle Norge. Et mangfold av tro oglivssyn", Statistics Norway: http://www.ssb.no/ssp/utg/200903/03/

Døving, Alexa, Sidra Shami and Tore Lindholm, 2011: "Religious Commitment and Social Integration: Are There Significant Links? A Pilot Study of Muslims in the Oslo Area with a Family Background from Pakistan”, University of Oslo Faculty of Law Research Paper No. 2012-01. Available at http://papers.ssrn.com/sol3/papers.cfm?abstract_id=1978709

Eidsvåg, Inge and Oddbjørn Leirvik, 1993: Fellesskapsetikk $i$ et flerkulturelt Norge.Universitetsforlaget, Oslo. 
Eidsvåg, Inge and Lena Larsen, 1997. Religion, livssyn og menneskerettigheter i Norge. Universitetsforlaget, Oslo.

Gardell, Mattias, 2007. Bin Laden i våre hjerter. Globaliseringen og fremveksten av politisk islam. Spartacus, Oslo.

Grung, Anne Hege, 2004: “Kvinneperspektiv på kristen-muslimsk dialog”, in Lissi Rasmussen and Lena Larsen (eds.): Islam, kristendom og det moderne, Tiderne Skifter, Copenhagen.

Hagen, Carl I., 2007: Arlig talt. Memoarer 1944-2007. Cappelen, Oslo.

Integreringsbarometeret, 2009: "Holdninger til innvandring, integrering og mangfold", in IMDi-rapport 4-2010, pp. 30-31 and 59-66: "Synet på muslimer og islam”.

Ishaq, Bushra, 2009: "Muslimer i endring." Aftenposten 4 September 2009, http://www.aftenposten.no/meninger/kronikker/article3252237.ece

Jacobsen, Christine M., 2002. Tilhørighetens mange former. Unge muslimer i Norge. Pax, Oslo.

Kastoryano, Riva, 2004: "Religion and Incorporation: Islam in France and Germany", International Migration Review, 38, 3: 1234-1255.

Kristensen, Adrianne Kelly, 2010: “'Sint muslimsk ungdom'. Representasjoner og resepsjon avbegrepet 'radikal islam' i global og lokal kontekst'. Master's thesis, Faculty of Theology, University of Oslo.

Larsen, Lena, 2010: “Striden om Muhammed”, Dagbladet 13 February 2010.

Leirvik, Oddbjørn, 2011: “The Cartoon Controversy in Norway: The New Christian Right and Liberal Fundamentalism confronting Islam?” in Ulrika Mårtensson, Jennifer Bailey, Priscilla Ringrose, Asbjorn Dyrendal (eds): Fundamentalism in the Modern World, volume 2: Culture, Media and the Public Sphere.London: I.B. Tauris 2011, pp. 125-146.

Leirvik, Oddbjørn, 2009: “Aktivt støttande religionspolitikk - på kva vilkår, til fordel for kven?" Norsk Teologisk Tidsskrift 2 66-88.

Leirvik, Oddbjørn (ed.), 2004: “Intervju med og forsking på muslimske elevar sitt forhold til KRL-faget og deira måte å artikulere sin identitet på”, web-article: http://www.tf.uio.no/evu/KDLoppgaver/MuslimarKRL.htm 
Leirvik, Oddbjørn, 2003: "Islam and Christian-Muslim Relations in Norway. Popular Realities, Political and Religious Responses, Interfaith Cooperation", in Islamochristiana 29: 121-140.

Leirvik, Oddbjørn, 2001: Religionsdialog på norsk. Ny og utvida utgåve, Pax, Oslo.

Roald, Anne-Sofie, 2001: Women in Islam. The Western Experience. Routledge, London.

Sultan, Shoaib, 2005: Muslimer i statskristendommens land, in D. Søderlind (ed.): Farvel til statskirken? Humanist forlag, Oslo, pp. 83-92.

Tronstad, Kristian Rose, 2008: "Religion", in Levekår blant innvandrere i Norge 2005/2006: Statistisk Sentralbyrå.

Vestel, Viggo and Øia, Tormod, 2007: Mфter i det flerkulturelle (NOVA Rapport 21/07), NOVA, Oslo.

Waardenburg, Jacques, 2000: "Muslims and Christians: Changing Identities', in Islam and Christian-Muslim Relations 11, no. 2, pp. 149-162.

Østberg, Sissel. 2003. Pakistani Children in Norway. Islamic Nurture in a Secular Context Department of Theology and Religious Studies, University of Leeds. 